Positioning, similarity, and difference:

\title{
Narratives of individual and organizational identities in an Australian university
}

\author{
Abstract \\ This study looks at a large Australian university at a time of reform in the higher \\ education sector to examine how the identities of individuals working within the university, as \\ well as the university itself, were constructed. By examining the narratives that organizational \\ members told, the study shows how academics, senior executives and general staff members \\ constructed identities through different patterns in the interplay of similarity and difference \\ among actors, doings and perceptions, as a result of which positions were ascribed to and \\ taken up by individual and collective actors.
}

\section{Keywords}

Organizational identity, narrative, positioning, similarity, differentiation 


\section{Introduction}

Recent changes in the higher education sector around the world have meant that researchers have become increasingly interested in the effects of managerialism and marketization in universities. In particular, studies have examined how managerial practices related to wider sectoral reforms have influenced academics’ identities (e.g., Barry, Berg, \& Chandler, 2006; Humphreys \& Brown, 2002).The work on universities forms part of the larger body of literature that has investigated how organizational and individual identities are formed, particularly through the complex ways in which people relate themselves to organizational identities (e.g., Holmer-Nadesan 1996; Larson \& Pepper, 2003); as well as how identities are affected by broader changes associated with the rise of the enterprise culture, new public management and marketization (du Gay, 1996; Thomas \& Davies, 2002).

This study of a large Australian university, at a time of higher education reform, examines how organizational identities - both individual and organizational - are constructed from the narratives that organizational members tell as they talk about specific events in their organizational life, their experiences and their concerns. In telling these narratives, individuals talk about themselves, the group they belong to, other groups, their organization, other organizations, etc. Our findings show how, through particular interplays of similarity and difference, speakers position themselves in relation to other identities, both individual and collective, as well as the audience being addressed. Through this process, particular individual and organizational identities are formed and different outcomes are achieved.

In carrying out this study, we extend the application of identity studies in higher education to the Australian context. We also provide a comparison of the identity narratives of different groups within the university - academics, senior executives and members of the general staff. Our study also shows how different patterns in interplays of similarity and difference and in positioning can provide a creative space for actors to construct narratives 
that produce quite different outcomes. Our study thus contributes greater insight into the nuances of the process of identity work, as well as its outcomes.

This paper is organized as follows. We first review the theory on the construction of identity. We then introduce the case study and present an overview of how we collected and analyzed the data. Third, we present our findings. Finally, we discuss the implications.

\section{The Construction of Identity}

The concept of organizational identity has been of considerable interest to researchers over the last 20 years. Albert and Whetten's (1985) work on organizational identity sparked a burgeoning interest among organization scholars. These authors defined organizational identity as the construct that members use to describe what is central, enduring, and distinctive about their organization. In this literature, how people relate themselves to the organization's identity is understood in terms of organizational identification, which is defined as a perception of oneness with or belongingness to an organization (Ashforth \& Mael, 1989). Much of this work has emphasized member convergence around a "strong” organizational identity which, in turn, is believed to have positive outcomes for the individual and the organization (Brown \& Starkey, 2000). A major research initiative has therefore been to identify ways by which managers can create strong, convergent organizational identities with which members can easily identify (Pratt \& Foreman, 2000).

This literature has, more recently, become more aware of multiple organizational and individual identities, which may complement or contradict each other (Pratt \& Foreman, 2000). As a result, the focus has expanded to include instability (Gioa, Shultz, \& Corley, 2000); hybrid identities (Golden-Biddle \& Rao, 1997); identity conflict (Glynn, 2000); the dysfunctional aspects of a strong identity (Fiol, 2002); and the role of external stakeholders in constructing identity (Scott \& Lane, 2000). Maguire and Hardy (2005, p. 15) have argued, however, that such attempts to introduce complexity and ambiguity have been "hampered by 
a definition based on durability, convergence and unity" and one way "to overcome these difficulties is to examine identity from a postmodern perspective”, which challenges the idea of strong, convergent identities, arguing instead that identities are multiple, fragmented, and contradictory (e.g., Hopkinson, 2002; Brown, 2006).

Such research has found that individuals relate themselves to their organization in multiple, ambivalent, and conflicted ways (Larson \& Pepper 2003; Maguire \& Hardy, 2005). In addition, organizational members question, alter, ignore and reject managerial efforts at aligning people’s identification with managerial interpretations of organizational identity (Humphreys \& Brown 2002; Thomas \& Davies 2005; Currie \& Brown 2003). Thus different forms of identification emerge, including disidentification. For example, Holmer-Nadesan’s (1996) study showed how female service workers in a university either rejected the formal definition of organizational identity (counter-identification) or eschewed managerially sanctioned organizational identity in favor of alternative identities (disidentification). Similarly, Humphrey \& Brown’s (2002) study of an educational institute showed that, while some individuals did identify with the organization, others engaged in disidentification; schizo-identification; and neutral identification. Thus there is a range of ways in which individuals can connect to - or distance themselves from -an organizational identity.

This research shows that individuals are active in processes of identity construction. Despite leaving room for individual agency, the work on recent public sector reforms, such as the move towards enterprise (du Gay, 1996) and new public sector management (Thomas \& Davies, 2002; 2005), has emphasized the degree to which these broader discourses influence and constrain - processes of identity construction. In the case of universities, reforms have required change in organizational identities, as they become more commercial, strategic, and concerned with quality assurance, evaluation, auditing, and course accreditation (e.g., Parker \& Jary, 1995; Prichard \& Willmott, 1997; Engwall, 2007). The resulting changes have placed 
additional and often competing demands on individual academics (Barry, Chandler, \& Clark, 2001), leading to: work intensification and loss of autonomy (Davies \& Thomas 2002): increased administration (Czarniawska \& Genell 2002; Ylijoki 2005); more stringent peer review (Barry et. al. 2001); and the introduction of managerial techniques (Trowler, 2001; Barry et. al. 2006). As a result, studies have examined the (re)construction of academic identities as individuals attempt to cope with these pressures. For example, Barry et al. (2006) show how academics have constructed different identities in both defensive and proactive responses to managerial reforms, including the Stressed Professor, the Managerial Advocate, the Administrative Patrician, the Accidental Female, the Academic Chameleon and the Resolute Researcher.

\section{Narratives}

This study builds on the work that shows how organizational and individual identities are constructed in and through the narratives told by organizational members (Humphreys \& Brown 2002; Chreim, 2005; Brown, 2006). A narrative is defined here as a “meaning structure that organizes events and human actions into a whole, thereby attributing significance to individual actions and events according to their effect on the whole” (Polkinghorne, 1988, p. 18). Narratives are a useful interpretive lens with which to understand identity formation because they act as devices for people to make sense of past events and actions (Reissman, 1993); to present themselves and others (Horrocks \& Callahan, 2006); to share meaning in a collectivity (Ylijoki, 2005); and to provide legitimacy and accountability for their actions (Czarniawska, 1997; Currie \& Brown, 2003). As sense making device, narratives allow individuals to “fashion” their own identities (Rosenwald \& Ochberg, 1992) in the stories they tell about themselves (Ainsworth \& Hardy, 2004a). In constructing his or her own identity through narrative, an actor also constructs the identities of others (Davis \& Harré, 1990). As "narratives are fashioned more generally to explain events, excuse failures, 
promote particular outcomes, etc., both individual and organizational identities are constructed" (Ainsworth \& Hardy, 2004a, p. 162), producing a "figured world” (Kitchell, Hannan \& Kempton, 2000) from which the identities of its participants, the relationships among them emerge (Gergen, 1994). As story telling creatures (Brown 2006), people link individual human actions and events into a meaningful whole through the narratives they tell (Polkinghorne, 1988), in particular through selective sequencing of events, attribution of motive to characters in the story, and assignment of moral qualities to themselves and others processes which are all crucial in the formation of identities (Brown 2006),

Identity construction through narration typically occurs through the ways in which the narrator positions him/herself in relation to other actors (Davis \& Harré, 1990). This positioning involves a "process of differentiation, a description of one’s own group and simultaneously as separate from the "others” (Wodak, 1996, p. 26). In other words, the Other is constructed not only as different, but also as less desirable, powerful and acceptable (Hall, 1997) i.e., “a description of one’s own group in opposition to and separate from less desirable others” (Maguire \& Hardy, 2005: 35). Identity “is achieved by differentiating and excluding that which is 'Other”” (Ainsworth \& Hardy, 2007, p.297). Such “othering” may, however, also include identification with, and inclusion of, other individuals and groups as “identities normally conceptualized as belonging to some other and different constituency [are] recognized as being applicable to themselves” (Maguire \& Hardy, 2005, p. 35).

Positioning also includes the audience to whom the narration is addressed. The audience is important because any narrative has to be negotiated between the teller and the listener (Czarniawska, 1997) if the narrative is to be accepted as legitimate (Reissman, 1993; Gergen, 1994). Sometimes, the audience may reinforce and reproduce the narrative. For example, Chreim (2005, p. 585) shows how the narratives told by senior managers concerning a Canadian bank’s identity “were anticipated, often applauded, and [only] occasionally edited 
by the business press.” Narratives can also be corrected by the audience, as in the case of a study of alcoholics’ narratives (Kitchell et al., 2000); and some narratives may fail completely (Humphreys \& Brown, 2002). Thus narratives are implicated in each other - as members of one group spin narratives about themselves and others, their tales are influenced by the narratives spun by members of these other groups: different groups represent both teller and audience as narratives are told to each other. This occurs through "a continuous process of narration where both the narrator and the audience formulate, edit, applaud, and refuse various elements of the ever-produced narrative' (Czarniawska-Joerges, 1994, p. 198).

The identities that emerge from such processes are not neutral - they can have material effects and lead to particular outcomes (Ainsworth \& Hardy, 2004b). For example, studies have shown how organizations use a range of discursive resources to promote certain versions of refugee identity, which protect and support their own identities and which lead to different outcomes for the refugees themselves (Phillips \& Hardy, 1997; Hardy \& Phillips, 1999). Similarly, studies have shown how health and aged care services are influenced by the construction of age identities (Yalnne-McEwen 2000; Ainsworth, 2002). Variations in how the identity of the older male worker is constructed can be associated with different policy outcomes (Ainsworth \& Hardy, 2007). So far, however, the outcomes or effects of particular identities have not been studied in any great detail in universities

In sum, we are interested in how identities are constructed in the light of current university reforms and, specifically, whether Australian experience conforms to findings in other countries. Second, we are interested in examining the micro-dynamics of such identity work to identify whether these processes differ in the case of academic and administrative identities. Third, we are interested in ascertaining the effects or outcomes of these processes. 


\section{Methods}

This study involves a large Australian university, referred to here as "the University", which we selected for several reasons. First, as universities have widely acknowledged categories of membership (e.g., academics, administrators, etc.), each of which has a story to tell about themselves, each other, and the organization, thus enabling us to look into the complexity of how organizational identities are narrated into existence. In this way, we can compare academics, senior university executives, and general/administrative staff members. Second, organizational identity has been shown to be particularly salient in time of organizational change (e.g., Albert \& Whetten, 1985; Humphreys \& Brown, 2002), which makes the University an appropriate setting given the changes described below.

The study adopts a single-case approach (Yin, 2003; Eisenhardt, 1989) to unpack the narrative process of identity formation and to enable us to look into the complex processes involved as people narrate their views and experiences about working in the university. Given that our interest is to understand how people construct identities in a specific context, a single case approach, while limited in terms of generalization (Taylor \& Bogdan, 1998), is nonetheless appropriate for a deep, interpretive and holistic understanding of the phenomena in question (Yin, 2003): by focusing on a single case, we are able to conduct a more detailed analysis of the micro-dynamics of identity construction.

\section{The University}

The University is one of the oldest institutions of higher education in Australia, established in the 1800s. During its first one hundred years, the University taught a small privileged segment of the state's population, with little interference from the government. The University’s student population surged after the Second World War when the Liberal federal government poured more money into the sector to finance the studies of returning military service personnel and, again in the early 1970s, when the Labor government took over the 
financial responsibility for student fees. Amidst an economic recession and the onset of a more economic rationalist approach during the late 1980s, the federal government reduced the number of Australian universities through a process of amalgamation, and introduced a sector-wide framework for funding; compliance measures for accountability; and managerial structures such as strategic planning. The government also removed quotas on international student admissions and replaced free tertiary education with the Higher Education Contribution Scheme (HECS), which required students to contribute to the cost of their education upon reaching a threshold income after completing their degree. In response to these changes, the University overhauled its committee system to give more authority to those responsible for the implementation of its strategic plan, introduced a staff appraisal system, and implemented programs to enhance its performance on key indicators.

In the mid-1990s, the newly elected Liberal federal government continued its predecessor's decision not to increase higher education funding to support future expansion. The University's Vice Chancellor at that time embarked on a strategic plan to make the University "one of the finest universities in the world”. The plan recognized that this goal was unattainable with current levels of funding. To expand its resource base, the University began to actively recruit international students, incorporated a private university arm, and founded an online educational initiative with other research universities around the world. Of these strategies, only international recruitment was financially successful, as the proportion of international students increased from six to 20 percent over ten years and, by 2005, around thirty percent of students were fee-paying.

Recently, the University has been calling for the introduction of a new degree model which involves offering of small number of three-year undergraduate degrees to be followed by a wider range of two-year specialist professional graduate degrees. In ten years, it hopes to transfer a portion of its student places from undergraduate to graduate levels. The model has 
been presented as a way to differentiate the University from its competitors and also to stem the growth in student numbers in recent years, without adversely affecting income. In addition, all departments are to be assessed to see whether they are in the top three in the country as far as their area of research is concerned. Funding is to be channeled to the stronger research areas. Finally, there are plans to intensify the University’s engagement with the wider public through a wide array of means ranging from organizing lectures on topics that are of interest to the community to greater research collaboration with industry.

\section{Data Collection}

Consistent with other studies of identity (e.g., Humphreys \& Brown, 2002; Thomas \& Davies, 2002; Brown et. al., 2005; Maguire \& Hardy, 2005), this study uses texts generated from interviews with 26 selected employees in the university, five of whom were approached for a follow-up interview to capture their views and involvement in the strategic planning which had barely started at the time of the original interview. To explore the contextspecificity of identity formation, interviews lasting between 45 to 90 minutes were conducted with academics; senior executives; and general staff members. Academics were mostly male and had been employed by the University for as little as two years to as long as three decades. General staff were mostly female; were either involved in academic support or marketingrelated function; and had been in the University from two to 20 years. Except for one, all the senior executives were also academics and had been involved in the implementation of the reforms that took place since the mid-1990s.

The initial 22 interviewees were randomly selected by the University’s human resource department and invited to participate in the study. Another 4 were referred to the first author by other interviewees. Questions were loosely structured and revolved around the participant's reasons for working in the University; what they liked and disliked about working in the organization; how their views of and experiences in the organization had 
changed over the years; the participant's problems at work and how he/she dealt with them; and their involvement, if any, in the ongoing strategic planning process. All the interviews were audio taped and then transcribed. In addition to the interviews, a number of public documents were collected to provide a detailed understanding of the context. Among these documents were comments and reports submitted to and uploaded on the University's website by academics, researchers, and managers as part of the consultation related to the strategic planning process. The first author also observed four public consultative meetings conducted by University administrators to obtain feedback on the interim strategic plan.

\section{Data Analysis}

In the first stage of the analysis, we analyzed all the interviews to identify whether a narrative could be discerned from what was said in the interview. Specifically, we examined in general terms whether there were relationships between the parts and the whole i.e., the setting, events, focal actors or characters in the story, the complicating actions, and resulting outcomes (cf. Mishler, 1986). We first identified the events being talked about and the setting in which these events took place (i.e., entrepreneurial reform in the university sector in the last decade). We then identified the characters in the narrative by ascertaining which actors the narrator and other characters in the narrative - including collective actors, such as the narrator's group, other groups, the narrator's organization, or other organizations - were named in the story. We then took note of any complicating action or evaluative commentary made by the speakers on the events, conflicts, or themes. In this way, we were able to differentiate narratives that referred to the same event, but differed in terms of the actors they implicated and the complicating actions they implied. From this process, we inferred the meaning of the narrative that was being conveyed from the author to the audience.

In the second stage of analysis, we constructed a "second order" categorization of the individual narratives. We did so by comparing and contrasting the individual narratives in 
ways that allowed us to cluster them in meaningful groupings. This was a highly iterative and inductive process as we went back and fourth between the data to see whether and how the individual narratives could be compared and then clustered in a meaningful categorization. From this process, we identified a listing of the different narratives told by the interviewees. Some were told by many interviewees; some were more idiosyncratic and told by only one or two interviewees. Because we wanted to compare narratives across the three different groups - academics, senior administrators and general staff members, we selected the two most common categories of narrative told by each group for further analysis. While we do not claim that they are necessarily representative of all the narratives told in the University, we did take steps to ensure they resonated in the large community. We did so by consulting some of the naturally occurring texts (e.g., feedback essays) and field notes of meetings to see whether there was any evidence of similar themes; and found that there were. We therefore concentrated subsequent analysis on these six categories of narrative.

In the third stage of analysis, we first examined each category of narrative collectively to see evidence of “othering” i.e., patterns that indicated an interplay of similarity and/or difference between different objects. Our analysis showed that these interplays occurred between actors (individual and collective identities); doings (activities, practices, events, or outcomes); and perceptions (particular interpretations offered by different actors). Further, we ascertained that speakers compared and differentiated these objects in three main ways: (a) similarity; (b) attribution of difference; or (c) affirmation of difference. In the case of similarity, speakers established the commonality between the objects of differentiation. In attribution of difference, the identity of an object was established by differentiating it from others. In affirmation of difference, speakers highlighted the uniqueness of the objects being identified without comparing it to other objects. We then systematically examined how the narrator positioned him/herself in relation to other individual and collective identities; and in 
relation to the audience. Positioning analysis asks the questions 'who/what is doing to whom/what in the narrative?' and 'how is narrator situated to the audience?'

Throughout this process, we compared and contrasted patterns of interplay and positioning across the six narratives and across the three employee groupings. In this way, we were able to show how different narratives constructed different individual and collective identities and, further, to establish what the narratives "do" in the immediate context of the narration (cf. Bamberg, 2006), as discussed in more detail in the following section.

\section{A Reflexive Note}

We are aware of the limitations with this study; and with the use of a single case study in particular, which reduces the ability to generalize from the findings. We acknowledge that the interviewees who participated may be biased insofar as they were initially identified by the Human Resource Department although, as far as we are aware, in a random manner. It is also case that those who agreed to participate might be those most interested in telling their particular narratives i.e., the most vocal. So, we are not suggesting that those studied here are privileged in any way (other than by us); nor do we dispute that other narratives exist. We admit that the narratives identified here may not have occurred without the existence of a willing audience - the interviewer - although our background analysis of documents and participation in meetings indicate that these stories have been told in other contexts. We recognize that our data was shaped by the immediate context of the interview, in particular the interviewer's presentation of himself as postgraduate student researcher and the participants' personal views of the interviewer as researcher, i.e. sympathetic, complicit, noncommittal, skeptical, etc. As academics doing identity research, we were interested in the effects of recent reforms on the identities of our participants and the University. Our theoretical focus has led us to focus on identity-related narratives and to ignore other narratives that did not relate so specifically to identity. Thus the narratives that we present as being told by the 
interviewees are also products of our interpretations and influenced by our theoretical interests - which makes them as much our narrative about individual and collective identities as those of the participants.

\section{Findings}

In this section, we discuss the findings. We show six different categories of narrative as told by academics, senior executives, and general staff - and look more closely at the interplays of similarity and difference and the positioning that occurs in each of them. ${ }^{1}$

\section{Narratives Told by Academics}

The two most common narratives told by academics were labeled pressure and mutation. We first present the different narratives and then explore differences and similarities in interplay and positioning between them.

\section{Narrative of Pressure}

This narrative emphasizes the impact of the reduction in federal funding in higher education and other government policies, which mean that the University is "much more dependent on [student] fees”. As a result, its main focus has been “attracting international students and domestic full fee students”, which has led to “declining staff and student ratios”. Academics now have to deal with "a lot more students than used to be the case”. This makes it "more difficult to do more research" especially now that research performance appraisal has become "more output driven”. While this narrative acknowledges the benefits of a more diverse international student body, academics also talked about the adjustments they have to take to accommodate international students, the "majority of whom have difficulties with communication”. They also bemoan the quality assurance systems imposed by the federal government which takes up a lot of their time. These changes may be seen as "good in themselves”, but they put “more pressure on people...when they’re all put together”. As one

\footnotetext{
${ }^{1}$ In presenting this analysis, please note that phrases in double quotation marks are taken from the interviews in which the particular narrative was told; our descriptive terminology is in italics.
} 
academic said, "I think people work a lot harder [and] longer hours than when I first came here. People feel more under pressure than they did.”

Academics are the focal actors in this narrative, presenting themselves as being subjected to greater pressures as a result of the entrepreneurial reforms and compliance requirements introduced in the university. Overworked academics "suffer" the consequences of actions imposed by the agent, in this case, the federal government. Solutions that address this problem are therefore seen in a positive light. For example, speakers talk about the pedagogical benefits offered by the new degree model. Although acknowledged as "potentially risky”, it can address the issue of work intensification brought about by the "diminution of federal government support and ...the introduction of fee paying students". Moreover, as an "entrepreneurial” and "well-resourced” institution, this University is in the best position possible to take on such major change.

\section{Narrative of mutation}

This narrative acknowledges the role of the government policy in causing pressure, as well as the role that senior executives in the University played in this process. Unlike the narrative of pressure, the cause of these entrepreneurial reforms is not just some distant federal government in the nation's capital, but people closer to home - the "managers” and “central administrators”. In other words, the way in which senior executives had responded to government policy had increased the pressure.

The University is obviously much more concerned about its revenue sources. So it has to set up whole system to advertise to students, and process the fees, and so forth, so that's been a very significant change (academic).

Increased student numbers, for example, has meant that the University has put in place standardized practices in handling classes which, academics argue, are more to "protect the students” than for pedagogical reasons. 
The resulting changes have helped to transform the University. The "entrepreneurial” push and the emphasis on projecting the University as "world class" despite "problems in various areas" have distracted it from its true mission of doing "good teaching and research". In this narrative, the proposed new degree model is simply another "scheme designed to bring in more revenue” and “a way of getting around the [government-imposed] 35 percent restriction" on domestic fee paying students. There are concerns that it will favor "those with money to be full fee paying students” and “exclude those people of general ability”, who are not eligible to compete for scholarships. Instead of pursuing this “marketing approach”, the University should be "more active in putting more pressure on the government". The narrative thus calls for the University to reclaim its place as a “public’ institution by lobbying for increased public funding, instead of relying on entrepreneurial activities.

\section{Interplay and Positioning}

Both these narratives attribute differentiation between past and present doings. Academics highlighted the problems arising from recent reforms by differentiating the present from the past, when there were "fewer students" and less "demand in terms of what you might call clerical, bureaucratic, or administrative requirement”. In both narratives, the speakers look to the past with nostalgia:

When I started here in the 1970 s... we could spend so much more time in marking. In fact we do a more effective job in helping people to improve because we spend a year with students and most lecturers took most of the tutorials (academic).

When I first came here, people would often have lunch together or socialize after work and people now are more likely to just work the whole time (academic).

This temporal differentiation of practices (past vs. present) articulates the deterioration of academics' working conditions, enabling speakers to position themselves as the victim in the narrative, while the federal government is the perpetrator of these policy changes that 
have caused academics - and as well as the University as patient - to suffer. In the process, the identity of an "overworked academic" is constructed in both narratives.

The narrative of pressure also attributes differentiation between present and future doings, namely the current conservative practices of the University and the newly emerging entrepreneurial practices. In so doing it positions a present “conservative” organizational identity in relation to a future (desirable) “entrepreneurial” identity. Thus there is an emerging University identity which, while it may take time to achieve, will replace the older, conservative identity. In contrast, the narrative of mutation attributes differentiation to perceptions of the University - the real and the hype. Thus two versions of the University's identity are introduced - a "hyped up”, marketing-driven identity that is different to, and not reflective of, the "real" identity of the University, which is a "good" but not necessarily "world class" institution. In differentiating the real identity of the University from the hype, the narrative criticizes the entrepreneurial activities that are distracting the University from its true mission, which should be “developing its research, and encouraging staff to do a bit more research while also setting high standards in teaching and postgraduate work”. In this way, a different set of actors is introduced - and differentiated from the academic narrators - the senior executives who are responsible for responding to the broader sectoral reforms, and who are held accountable for pursuing the false, hyped identity.

In sum, both narratives allow speakers to voice grievances regarding the pressures they have endured. The absence of active agents - except for a distant and immutable government - in the narrative of pressure absolves University members of the responsibility of finding solutions. Moreover, since the emerging identity of the University - as entrepreneurial - is relatively positive, there is a relative receptiveness to the changes that are being proposed. In contrast, the narrative of mutation not only expresses a grievance, it also critiques the hyped version of the organizational identity. This identity is illusory, mistakenly 
pursued by senior executives who, rather than allowing the University to mutate into something alien, should, instead, be looking towards the University’s past identity (Table 1).

- Table 1 near here -

\section{Narratives Told by Senior Executives}

The two most common narratives told by senior executives were of adaptation and innovation, as discussed below.

\section{Narrative of adaptation}

Like their academic peers, senior executives agreed that recent changes in government policy had impacted on the University a great deal. The federal government is still cast as the source of pressure, as a result of its decision not to fund future growth of universities. This policy left the University with two options: either to "cut back on [its] programs" or "embark upon a revenue raising strategy" to access "new discretionary sources of income”. The latter path had been chosen because the University had to find a recurrent source of money that "was going to support the kind of educational programs that (they) wanted to pursue”, and “that of course drove the University to a much more entrepreneurial era”.

[P]eople saw that if [the University] was going to continue to be recognized as a premier university both in Australia and overseas, then we needed to endeavor to resource the university at levels that could make [it] competitive (senior executive).

Such changes were needed if the University was to maintain its position in relation to European and US institutions, as well as some Asian institutions in countries 'where the incountry capacity at least for undergraduate education has increased a great deal'. It was expected that in the future, more Asian students might prefer to stay home for their undergraduate education resulting in a smaller market for international students. The University therefore had to reposition itself to attract "quality students" if it was to "stay in the top tier of the universities around the world”. In other words, government funding 
reductions were jeopardizing the University’s “premier” position and senior executives had been forced to make changes in order to make sure that this position was not lost; and to keep the University in a leadership position relative to other institutions.

\section{Narrative of innovation}

In this narrative, the decision to be more entrepreneurial was not simply a reaction to a difficult funding situation but the beginning of a transformation that would greatly benefit the University. As it became more "commercial in [its] activities”, activities had been introduced that, in the past, people "would not dare mention," in particular, the "M words" like “marketing, management, management information”. With the "reduction in government funding, the University has to raise huge amount of revenues” which brought in "more management techniques and people with those skills”. These changes opened up possibilities for introducing new practices - like performance appraisal and branding - which, while they may have been resisted at first, had ultimately improved the University. The "new revenue streams" had allowed the University to "invest in new infrastructure, more staff and research related activities." The internationalization of the student cohort had led to a "greater emphasis on teaching” and while it may have forced academics to adjust their teaching styles, students benefited from a "wider educational experience” resulting from increased diversity. In days gone by, we have your security of tenure once you've got your job, you have it. In these days...it will be a condition of confirmation that you teach well so there's more emphasis on good teaching and if you're a good researchers and not a good teacher then you will be assisted to improve your teaching... (senior executive). In this narrative, the changes were not just a means to an end - a way of protecting the University’s leading position - nor had senior executives been forced into adopting them. The changes in practices were part and parcel of the University's leadership position - they were the way to keep it “'in line with trends worldwide”. For instance, it has been argued that 
people will support the proposed degree model because it will "increase the mobility of students and graduates and ...enable people to have more portable qualifications”. According to this narrative, government policy had made the University a better institution because of the way in which they had acted as a catalyst for a series of new practices that were not simply a defence mechanism but a proactive strategy for international eminence

\section{Interplay and Positioning}

Like their academic colleagues, senior executives in both narratives agreed that recent changes in government policy had impacted on the University a great deal. Thus there was attributive differentiation between past and present; but with a far more positive accent attached to the differences than in either of the two academic narratives. The present was not only different to the past; it was an improvement on it. In this narrative, the federal government was still cast as a perpetrator, and the University as a patient, but the prospects for recovery were far more optimistic. The nature of the differentiation between past and present enabled the narrators to see themselves as agents - part of the senior management team, and making responsible choices to maintain and improve the University. The University is thus constructed as a beneficiary from changes in which the narrator has played a key role.

Both narratives constructed the University as a "premier" or "leading” institution but in different ways. In the narrative of adaptation, it was important for the university to be similar to leading European and North American universities, and better than the up-andcoming Asian universities. In the narrative of innovation, being a premier/top tier university did not rely on any comparison with other specific objects; instead, the combination of affirmative differentiation of the University's identity coupled with similarity between present and future of organizational practices meant that success was directed at maintaining what was already a premier, top tier, world leader. Both narratives therefore provide justification for the reforms initiated by the senior management. However, with the adaptation narrative, 
senior executives justify their decisions as a legitimate defensive strategy in response to government - they did what they could in a difficult situation. In the case of the innovation narrative, senior executives adopt a proactive role - taking advantage of what could have been a negative situation perpetrated by the government and turned it around - preventing the University from falling prey and becoming a victim, it is now - thanks to the new practices that have been introduced finally living up to its leadership position (see Table 2).

- Table 2 near here -

\section{Narratives Told by General Staff}

The two most common narratives told by members of the general staff are of stress and discrimination, as discussed below.

\section{Narrative of stress}

General staff also endure the huge pressures put upon them by the changes. Senior executives and faculty managers are presented as the "source of pressure", although this narrative recognizes that they, too, are also subject to pressures in a "huge" and "targetdriven” university:

Faculties and departments around the university are under a lot of pressure to meet enrollment targets particularly for fee paying students that, in turn, puts a lot of pressure on us (general staff member).

Despite “working long hours or weekends...there’s a lot of things that just never happen”, especially when the central executive office calls and one "has to drop everything and run". Given the enormous “demands placed on senior executives to deliver a list of outcomes ...they're just interested in ticking the boxes off", which is "frustrating” to general staff members who are more concerned with being “creative" or doing the "the best” for the job. When these two objectives collide, senior executives reject the staff member's work without 
any explanation at all, “just like when [one’s] dad says no [and] you cannot really question decisions made from the top".

\section{Narrative of discrimination}

Some general staff members virtually ignored the changes going on inside and outside the institution and, instead, focused on their relations with academics. This narrative acknowledges that the University is a "prestigious” and "good employer” but many academics have a "bad discriminatory attitude towards general staff, treating them differently from how they treat their colleagues, and ...their students". The job of general staff members is "to do as told” or "do nearly whatever academics wanted from them”. In spite of this, academics are still "unhappy a lot of the time with what [general staff] did for them”. In this narrative, the predicament lies in the conservatism of the University:

I'm thinking that it may have something to do with a more conservative or more rigid attitude in the university. It may have something to do with the university’s image (general staff member).

The discrimination at this University is supposedly more pronounced compared to more "modern" universities in the state. This conservatism is also evident in terms of academics' tendency to resist change. In the processing of financial and academic requirements, for example, one "has to fight tooth and nail with academics" who are "very set in their ways" and behave in ways that hinder the implementation of essential changes in the organization.

The narrative indicates that staff members can fight discrimination, for example, by using humor, avoiding difficult academics, or helping those "who treat [general staff] with respect and decency" a little bit more. Being in the "thick of things", it may be possible for staff members to "put academics in their place”. In addition, general staff members are "professionals” and “providers of good service”, and can therefore resist by "working to rule”. 
$[\mathrm{M}] \mathrm{y}$ foremost concern is to do my job the best I possibly can while sticking to the written rules as I come across them (general staff member).

In other words, the general staff member are not completely without agency, both in terms of being good at their jobs and in knowing - and applying - the "rules of the game”.

\section{Interplay and Difference}

In the narrative of stress, attributive differentiation demarcates the self - the “pressured” yet “professional” staff member - from “demanding” and or “paternalistic” senior executives, who are the main perpetrators, although both groups are recognized as being subjected to stress as a result of the recent changes. General staff members are not without power because - unlike academics - they “know what's best for the job”; they are “professional” and “creative”. They can assert their technical knowledge, administrative experience, and creativity in relation to the changes being introduced into the University. As a result of these interplays, the general staff member is positioned as partly a victim, but also partly as a skilled professional. In expressing grievances in this way, this narrative critiques the work processes of senior executives and the way in which changes have been introduced.

In the narrative of discrimination, as general staff members talked about their unfavorable experiences with academics, they clearly differentiated themselves as "suffering" in relation to "conservative", "elitist” and "arrogant” academics. This act of differentiation enabled the speakers to describe the hierarchal relationships within the University and, in so doing, construct the University’s identity as conservative and traditional. In these accounts, general staff members take the position of the victim: not in relation to the changes that are being introduced; but in relation to an institutionalized "academic-general staff divide” in which academics are cast as the perpetrators of discrimination. In taking on the position of the victim and expressing these grievances, general staff members also acknowledge the dominance of the academics in the University and their exclusion from the broader University 
community. However, in excluding themselves, this narrative also opens up a space from which general staff members could "naturally question the arrogance, the traditionalism, or the conservative attitude" in the University. In differentiating the University from "modern" universities where general staff are supposedly better treated, these staff members also question the inevitability of their victim position (Table 3).

-Table 3 near here -

Our findings show how the self-identities constructed in each group: both academic narratives constructed academics as pressured and overworked; both narratives told by senior executives constructed them as part of the senior management team; while general staff members told two rather the narratives, one in which they were pressured; the other in which they were discriminated. However, a deeper analysis of interplay and positioning reveals rather more variation in terms of outcomes: the two academic narratives vary in terms of their support for the changes; both the narratives told by senior executives legitimize the changes one defensively and another proactively; one of the general staff narratives critiques work practices; while the other critiques hierarchy.

These differences are accomplished through the permutations that are possible in interplay and positioning. In the case of the narrative of mutation, for example, the inclusion of senior University managers in the story and their positioning as perpetrators/agents of entrepreneurial reforms and the construction of a real (vs. hyped) University produced calls for increased public funding (a return to the past), which did not occur in the narrative of pressure. In the narratives told by senior executives, their positioning as agents of reforms and the attributive differentiation of the present as an improvement of the past enabled the narrators to legitimize the practices they introduced and have recently proposed.

Thus certain narratives revolved around practically the same bundle of events and yet narrators drew on them differently leading to different identity constructions and outcomes. 
Thus in narratives told by academics, recent entrepreneurial practices or doings in the university might be discursively drawn upon to criticize what the University has supposedly become - 'entrepreneurial'. On the other hand, senior executives looked to the university’s 'premier' identity (past or traditional university) and to its goal of becoming a 'world class' university (future identity) to justify the recent entrepreneurial practices. In the narrative of stress, some of the general staff's attributive differentiation of themselves as 'pressured, creative, professional experts' to 'demanding but unqualified' senior academic executives not only highlights the aggrieved position from which they aired their grievance but also their exclusion from decision making activity in the university, thereby leading to the rejection of the work process brought about by the reforms and a critique of the executives themselves.

\section{Discussion and Conclusions}

Our research has shown that academics have been impacted by recent educational reforms in Australia in similar ways as those in the UK (Prichard \& Wilmott, 1997; Barry et. al. 2001), Sweden (Barry et. al. 2006) and Finland (Ylijoki 2005). Not surprisingly, we find evidence of two narratives told by academics which construct a self-identity of a pressured and overworked academic. While academics tended to present themselves as victims, senior executives told narratives in which they were active agents of the changes. The narratives told by general staff also constructed a disadvantaged self-identity: in one narrative, it took the form of pressure emanating from the changes; in the other, it took the form of discrimination resulting from a longstanding division between academics and non-academics.

Our study also shows how a range of organizational identities were constructed for the University, not so much as in the form of narratives in which the institution appeared as a clearly defined character (cf. Albert \& Whetten 1985; Ashforth \& Mael 1989), but through a more complex discursive process in which positions were ascribed to and taken up by individual and collective actors; and different interplays of similarity and difference between 
actors, doings, and perceptions were constructed. Different patterns in the way in which University practices were differentiated over time; how different persons and groups in the University were contrasted to each other; and how the University was compared to other universities, influenced the identity of the University in either a positive or negative light. For example, the attribution of past and present practices in the case of the narrative of pressure enabled academics to present themselves as overworked staff in a university that has been positively transformed from “conservative” to "entrepreneurial”. In contrast, attributive differentiation to perceptions of the University’s “real” identity against its hyped version, coupled with the positioning of senior executives as agents responsible for introducing these changes, led to the questioning of these entrepreneurial reforms. Thus the narratives served what might be termed a "surface" function in terms of a particular self-identity interacting in a particular way with an audience e.g., pressured academics airing a grievance or responsible managers explaining their actions to the interviewer. A deeper investigation shows how some of the narratives also achieved less visible functions e.g., they criticized or supported certain practices; established hierarchy among groups; attributed blame; and set boundaries for inclusion and exclusion.

The study also shows that participants can exercise agency and create spaces for resistance through the various permutations in the narratives, particularly in the form of victimhood positions. Previous research tends to suggest a dichotomy between some form of agency, where people are able to "wriggle” out of the identities (e.g., Doolin, 2002) and “victimhood”, which is seen primarily as subjugation (e.g., Ward \& Winstanley, 2004). In contrast, this study shows how victimhood as identity-making can play a strategic role for the different groups. For example, academics and general staff members cast themselves as victims - while this identity may appear to invoke subjugation, when taken in the context of the whole narrative it takes on a more active stance. Victims have been "wronged" by a 
perpetrator. Victims suffer not because of their own doing but because of circumstances beyond their control. Victims therefore have the right to moral indignation which allows them not only to share their predicament but also to critique the actions of those causing their suffering. Having been subjugated by events not of their own making, victims cannot also be expected to bear more than what they have already endured - they should be listened to and supported.

The narratives told by senior executives did not specifically cast any actor as victim. However, victimhood still played an important role in their identity narratives in two ways. First, the senior executives, by justifying at least some of their decisions in terms of relieving academics of the pressures they face, acknowledge, albeit implicitly, that there exist people who may be suffering and therefore require their help. Second, victimhood of the University is constructed as a very real threat, which must be kept at bay - by the University taking the drastic changes necessary to address the shifts in federal policy. Without the potential that both individuals and the institution might fall victim to the policy changes perpetrated by the federal government, the identities of senior executives as responsible and proactive managers would not make sense. Thus we can see how different narratives interpolate each other, with the effect that victimhood provides - in different ways - a resource for the identity work of the different groups. Future research might address this issue in more depth.

Finally, the findings show that, sometimes, challenges borne by university employees as a result of recent reforms take second place to older inequalities - such as the divide between academics and non-academics. For example, the advent of managerial and administrative reforms may provide an arena in which some general staff members can establish themselves as "professionals” but their narratives also show that, in doing so, they have to address the “discrimination” they face, which arises from a traditional and longstanding academic/non-academic divide. With all the attention on the injustices of recent 
government policies, it may be that we have forgotten that for some university employees, their working experience is affected less by new and radical reforms and more by age old status differentials; and future research might examine the ways in which these old and new discourses interact to impact on the identities of different groups of university employee. 


\section{References}

Ashforth, B. E. \& Humphrey, R.H. (1997). The ubiquity and potency of labeling organizations. Organization Science, 8(1), 43-58.

Ainsworth, S. \& Hardy C. (2007). The construction of the older worker: privilege, paradox and policy. Discourse and Communication, 1(3): 295-313

Ainsworth, S. \& Hardy, C. (2004b). Critical Discourse Analysis and Identity: Why Bother? Critical Discourse Studies, 1(2), 225-259.

Ainsworth, S. (2002). The “feminine advantage”: A discursive analysis of the invisibility of older women workers. Gender, Work and Organization, 9(5), 579-601.

Ainsworth, S. and Hardy, C. (2004a). Discourse and Identities. In D. Grant, C. Hardy, C. Oswick and L. Putnam, Handbook of Organizational Discourse (pp. 153-174), Sage. Albert. S. \& Whetten, D.A., (1985). Organizational identity. In L.L. Cummings and M.M. Staw (Eds.), Research in Organizational Behavior, (pp. 263-295). JAI Press, Greenwich, CT.

Ashforth, B.E. \& Mael, F. (1989). Social Identity Theory and the Organization. Academy of Management Review, 14 (1), 20-39.

Bamberg, M. (2006). Stories, big or small: Why do we care?. Narrative Inquiry, 16 (1), 139147.

Barry, J. Berg, E., \& Chandler, J. (2006). Academic shape shifting: Gender, management, and identities in Sweden and England. Organization, 13(2), 275-298.

Barry, J., Chandler, J., \& Clark, H. (2001). Between the ivory tower and the academic assembly line. Journal of Management studies, 38(1), 87-101.

Brown, A. \& Starkey, K. (2000). Organizational identity and learning: A psychodynamic perspective. Academy of Management Review, 25(1), 102-20. 
Brown, A. (2006). A narrative approach to collective identities. Journal of Management Studies, 43(4), 731-753.

Brown, A. and Humphreys, M. (2006). Organizational identity and place: A discursive exploration of hegemony and resistance. Journal of Management Studies, 43(2), 231-257.

Chreim, S. (2005). The continuity-change duality in narrative texts of organizational identity. Journal of Management Studies, 42(3), 567-593.

Currie, G. \& Brown, A.D. (2003). A narratological approach to understanding processes of organizing in a UK hospital. Human Relations, 56(5), 563-586.

Czarniawska, B. 1997. Narrating the Organization: Dramas of Institutional Identity, Chicago: University of Chicago Press.

Czarniawska-Joerges, B. (1994). Narratives of individual and organizational identities. In S. Deetz (Ed.), Communication Yearbook 17, (pp. 193-221). Thousand Oaks: CA: Sage.

Czarniawska, B. \& Genell, K. (2002). Gone shopping? Universities on their way to the market. Scandinavian Journal of Management, 18, 455-474.

Davis, B. \& Harre, R. (1990). Positioning: The discursive production shelves. Journal for the Theory of Social Behavior, 20(1), 43-65.

Doolin, B. (2002) Enterprise discourse, professional identity and the organizational control of hospital clinicians. Organization Studies, 23 (3), 369-90.

du Gay, P. (1996). Consumption and identity at work. London: Sage.

Eisenhardt K.M. (1989). Building theories from case study research. Academy of Management Review, 14(4), 532-550.

Engwall, L. (2007). The anatomy of management education. Scandinavian Journal of Management, 23(1), 4-35. 
Fiol, M. (2002). Capitalizing on paradox: The role of language in transforming organizational identities. Organization Science, 13(6), 653-666.

Gergen, K.J. (1994). Realities and Relationships: Soundings in Social Construction. Cambridge, Mass: Harvard University Press.

Gioia, D.A, Shultz, M, \& Corley, K.G. (2000). Organizational identity, image, and adaptive instability. Academy of Management Review. 25(1), 63-82.

Glynn, M.A. (2000). When cymbals become symbols: Conflict over organizational identity within a symphony orchestra. Organization Studies, 11(3), 258-298.

Golden-Biddle, K. and Rao, H. (1997). Breaches in the Boardroom: Organizational Identity and Conflicts of Commitment in a Nonprofit Organization. Organization Science, 8(6), 593-611.

Hall, S. (1997). The spectacle of the other. In S. Hall (Ed.) Representation: Cultural Representations and Signifying Practices (pp. 233-279). London: Sage, in association with the Open University.

Hardy, C. \& Phillips, N. (1999). No joking matter: Discursive struggle in the Canadian refugee system. Organization Studies, 20(1), 1-24.

Holmer-Nadesan, M. (1996). Organizational identity and space of action. Organization Studies, 17(1), 49-81.

Hopkinson, G.C. (2002). Stories from the front-line: How they construct the organization. Journal of Management Studies, 40(8), 1933-1969.

Horrocks, A. and Callahan, J.L. (2006). The role of emotion and narrative in the reciprocal construction of identity. Human Resource Development International, 9(1), 69 - 83.

Humphreys, M. \& Brown, A. (2002). Narratives of organizational identity and identification: a case of hegemony and resistance. Organization Studies, 23(3), 421-447. 
Kitchell, A., Hannan, E. \& Kempton, W. (2000). Identity through stories: Story structure and function in two environmental groups. Human Organization, 59(1), 96-105.

Larson, G.S. \& Pepper, G.L. (2003). Strategies for managing multiple organizational identifications. Management Communication Quarterly, 16(4), 528-557.

Maguire, S., \& Hardy, C. (2005). Identity and collaborative strategy in the case of Canadian HIV/AIDS treatment. Strategic Organization, 3(1), 11-45.

Mishler, E. (1986). The analysis of interview-narratives. In T. Sarbin (Ed.), Narrative Psychology: The stories nature of human conduct (pp. 233-255). Praeger: New York.

Parker, M. \& Jary, D. (1995) 'The McUniversity: Organization, management and academic subjectivity', Organization 2(2): 319-38.

Phillips, N., \& Hardy, C. (1997). Managing multiple identities: discourse, legitimacy and resources in the UK refugee system. Organization, 4(2), 159-185.

Polkinghorne, D. (1988). Narrative knowing ad the human sciences, State University of New York Press: Albany.

Pratt, M.G., and Foreman, P.O. (2000). Classifying managerial responses to multiple organizational identities, Academy of Management Review, 25(1), 18-42.

Prichard, C. \& Willmott, H. (1997). Just how managed is the Mcuniversity?. Organization Studies, 18(2), 287-316.

Reissman, C.K. (1993). Narrative analysis, Sage: Newbury Park, California.

Rosenwald, G.C. \& Ochberg, R.L (1992). Storied Lives: The cultural politics of self understanding. New Haven, CT: Yale University Press.

Scott, S.G., \& Lane, V.R. (2000). A stakeholder approach to organizational identity, Academy of Management Review, 25(1), 43-62.

Taylor, S.J. \& Bogdan, R. (1998), Introduction to qualitative research methods: a guidebook and resource, 3rd ed. New York : John Wiley and Sons, Inc. 
Thomas R. \& Davies, A. (2005). Theorizing the micro-politics of resistance: New public management and managerial identities in the UK public services. Organizational Studies, 26 (5), 683-706.

Thomas, R. \& Davies, A. (2002) Gender and new public management: Reconstituting academic subjectivities. Gender, Work and Organization, 9(4), 372-397.

Trowler, P. (2001). Captured by the discourse? The socially constitutive power of new higher education discourse in the UK. Organization, 8(2), 183-201.

Ward, J. \& Winstanley, D. (2004). Sexuality and the city: Exploring the experience of minority sexual identity through storytelling. Culture and Organization, 10 (3), 219-236.

Wodak, R. (1996). The genesis of racist discourse in Austria since 1989. In C.R. CaldasCoulthard and M. Coulthard (Eds.), Texts and practices: Readings in critical discourse analysis (pp. 107-128). Routledge: London.

Yin, R. (2003). Case study research: Design and methods ( $3^{\text {rd }}$ ed.), Thousand Oaks: Sage.

Ylanne-McEwen, V. (2000). Golden times for golden-agers: Selling holidays as lifestyle for over 50’s. Journal of Communication, 50(3): 83-99.

Ylijoki, O.H. (2005). Academic nostalgia: A narrative approach to academic work. Human Relations, 555-575. 
Table 1

Narratives told by Academics

\begin{tabular}{|c|c|c|c|c|c|c|c|}
\hline \multirow[t]{2}{*}{ Narrative } & \multirow[t]{2}{*}{ Interplay } & \multicolumn{3}{|c|}{ Position } & \multicolumn{2}{|c|}{ Identities } & \multirow[t]{2}{*}{ Outcome } \\
\hline & & Self & Other & Audience & Individual & Collective & \\
\hline Pressure & $\begin{array}{l}\text { Attributive } \\
\text { differentiation } \\
\text { between past and } \\
\text { present university } \\
\text { practices; } \\
\text { Attributive } \\
\text { differentiation } \\
\text { between present and } \\
\text { future university } \\
\text { practices }\end{array}$ & Victim & $\begin{array}{l}\text { Federal } \\
\text { government as } \\
\text { perpetrator of the } \\
\text { changes; } \\
\text { University as } \\
\text { patient }\end{array}$ & $\begin{array}{l}\text { Expressing a } \\
\text { grievance }\end{array}$ & $\begin{array}{l}\text { 'Pressured' or } \\
\text { ‘overworked' } \\
\text { academic }\end{array}$ & $\begin{array}{l}\text { 'Neoliberal' } \\
\text { federal } \\
\text { government } \\
\text { University as } \\
\text { moving from } \\
\text { 'conservative' to } \\
\text { 'entrepreneurial' }\end{array}$ & $\begin{array}{l}\text { Making sense of } \\
\text { past events; } \\
\text { Pushing for some } \\
\text { organizational } \\
\text { changes }\end{array}$ \\
\hline Mutation & $\begin{array}{l}\text { Attributive } \\
\text { differentiation } \\
\text { between past and } \\
\text { present university } \\
\text { practices; } \\
\text { Attributive } \\
\text { differentiation } \\
\text { between perceptions } \\
\text { of university; } \\
\text { Attributive } \\
\text { differentiation } \\
\text { between self and } \\
\text { senior executive } \\
\text { identities }\end{array}$ & Victim & $\begin{array}{l}\text { Federal } \\
\text { government and } \\
\text { senior executives } \\
\text { as perpetrator of } \\
\text { the changes; } \\
\text { University as } \\
\text { patient }\end{array}$ & $\begin{array}{l}\text { Expressing a } \\
\text { grievance; } \\
\text { Critiquing } \\
\text { the hyped } \\
\text { version of } \\
\text { organization } \\
\text { al identity }\end{array}$ & $\begin{array}{l}\text { 'Pressured' or } \\
\text { ‘overworked' } \\
\text { academic }\end{array}$ & $\begin{array}{l}\text { 'Neoliberal' } \\
\text { federal } \\
\text { government } \\
\text { Senior } \\
\text { executives as } \\
\text { 'goal setters' } \\
\text { 'Good' } \\
\text { university (real) } \\
\text { vs. 'World class' } \\
\text { (hype) }\end{array}$ & $\begin{array}{l}\text { Justification for } \\
\text { return to past } \\
\text { organizational } \\
\text { practices; } \\
\text { Establishment of } \\
\text { truth/false claims }\end{array}$ \\
\hline
\end{tabular}


Table 2

Narratives told by Senior Executives

\begin{tabular}{|c|c|c|c|c|c|c|c|}
\hline \multirow[t]{2}{*}{ Narrative } & \multirow[t]{2}{*}{ Interplay } & \multicolumn{3}{|c|}{ Position } & \multicolumn{2}{|c|}{ Identities } & \multirow[t]{2}{*}{ Outcome } \\
\hline & & Self & Other & Audience & Individual & Collective & \\
\hline Adaptation & $\begin{array}{l}\text { Attributive } \\
\text { differentiation } \\
\text { between past and } \\
\text { present } \\
\text { organizational } \\
\text { practices; } \\
\text { Attributive } \\
\text { differentiation } \\
\text { between this } \\
\text { University and Asian } \\
\text { universities; } \\
\text { Similarity between } \\
\text { University and } \\
\text { American and } \\
\text { European universities }\end{array}$ & Agent & $\begin{array}{l}\text { Government as } \\
\text { perpetrator of } \\
\text { change; } \\
\text { University as } \\
\text { patient }\end{array}$ & $\begin{array}{l}\text { Defending } \\
\text { decisions } \\
\text { leading to } \\
\text { changes in the } \\
\text { University }\end{array}$ & $\begin{array}{l}\text { Part of senior } \\
\text { management } \\
\text { team } \\
\text { defending the } \\
\text { University }\end{array}$ & $\begin{array}{l}\text { University as } \\
\text { 'premier' } \\
\text { institution in } \\
\text { relation to other } \\
\text { universities }\end{array}$ & $\begin{array}{l}\text { Legitimizing } \\
\text { organizational } \\
\text { change }\end{array}$ \\
\hline Innovation & $\begin{array}{l}\text { Attributive } \\
\text { differentiation } \\
\text { between past and } \\
\text { present } \\
\text { organizational } \\
\text { practices; } \\
\text { Similarity between } \\
\text { the present and the } \\
\text { future organizational } \\
\text { practices; } \\
\text { Affirmative } \\
\text { differentiation of } \\
\text { University identity }\end{array}$ & Agent & $\begin{array}{l}\text { Government as } \\
\text { perpetrator of } \\
\text { change; } \\
\text { University as } \\
\text { partly patient and } \\
\text { agent }\end{array}$ & $\begin{array}{l}\text { Explaining the } \\
\text { reasons for the } \\
\text { changes }\end{array}$ & $\begin{array}{l}\text { Part of senior } \\
\text { management } \\
\text { team } \\
\text { transforming } \\
\text { the University }\end{array}$ & $\begin{array}{l}\text { University as } \\
\text { moving from } \\
\text { 'conservative' to } \\
\text { 'entrepreneurial' } \\
\text { and becoming } \\
\text { 'one of the finest } \\
\text { universities in } \\
\text { the world' }\end{array}$ & $\begin{array}{l}\text { Legitimizing } \\
\text { organizational } \\
\text { changes }\end{array}$ \\
\hline
\end{tabular}


Table 3

Narratives told by General Staff

\begin{tabular}{|c|c|c|c|c|c|c|c|}
\hline \multirow[t]{2}{*}{ Narrative } & \multirow[t]{2}{*}{ Interplay } & \multicolumn{3}{|c|}{ Position } & \multicolumn{2}{|c|}{ Identities } & \multirow[t]{2}{*}{ Outcome } \\
\hline & & Self & Other & Audience & Individual & Collective & \\
\hline Stress & $\begin{array}{l}\text { Affirmative } \\
\text { differentiation of } \\
\text { self and senior } \\
\text { executives; } \\
\text { Affirmative } \\
\text { differentiation of } \\
\text { self and } \\
\text { academics }\end{array}$ & $\begin{array}{l}\text { Victim } \\
\text { (partly) }\end{array}$ & $\begin{array}{l}\text { Senior executives } \\
\text { as perpetrators of } \\
\text { change }\end{array}$ & $\begin{array}{l}\text { Expressing } \\
\text { grievances }\end{array}$ & $\begin{array}{l}\text { 'Pressured', } \\
\text { ‘creative' } \\
\text { 'professional' } \\
\text { staff member }\end{array}$ & $\begin{array}{l}\text { Senior } \\
\text { executives as } \\
\text { 'demanding' } \\
\text { and 'pressured } \\
\text { to deliver } \\
\text { outcomes' } \\
\text { Academics: } \\
\text { 'not qualified } \\
\text { in } \\
\text { management' }\end{array}$ & $\begin{array}{l}\text { Critique of the } \\
\text { work process } \\
\text { and the senior } \\
\text { academics; } \\
\text { emphasis on } \\
\text { importance of } \\
\text { general staff } \\
\text { contribution to } \\
\text { change }\end{array}$ \\
\hline Discrimination & $\begin{array}{l}\text { Attributive } \\
\text { differentiation } \\
\text { between self and } \\
\text { academics } \\
\text { Attributive } \\
\text { difference } \\
\text { between the } \\
\text { University and } \\
\text { other universities } \\
\text { in the state }\end{array}$ & Victim & $\begin{array}{l}\text { Academics as } \\
\text { perpetrators of } \\
\text { discrimination }\end{array}$ & $\begin{array}{l}\text { Expressing } \\
\text { grievances }\end{array}$ & $\begin{array}{l}\text { 'Discriminated' } \\
\text { 'professional' } \\
\text { staff member }\end{array}$ & $\begin{array}{l}\text { Academics as } \\
\text { 'conservative' } \\
\text { and 'arrogant' } \\
\text { University as } \\
\text { 'conservative' } \\
\text { and } \\
\text { 'traditional' } \\
\text { Other } \\
\text { universities as } \\
\text { 'modern' and } \\
\text { more } \\
\text { egalitarian }\end{array}$ & $\begin{array}{l}\text { Critique of } \\
\text { organizational } \\
\text { hierarchy }\end{array}$ \\
\hline
\end{tabular}




\section{University Library}

\section{- M M N E R VA A gateway to Melbourne's research publications}

Minerva Access is the Institutional Repository of The University of Melbourne

Author/s:

Garcia, P;Hardy, C

Title:

Positioning, similarity and difference: Narratives of individual and organizational identities in an Australian university

Date:

2007-12-01

Citation:

Garcia, P. \& Hardy, C. (2007). Positioning, similarity and difference: Narratives of individual and organizational identities in an Australian university. SCANDINAVIAN JOURNAL OF MANAGEMENT, 23 (4), pp.363-383. https://doi.org/10.1016/j.scaman.2007.09.002.

Persistent Link:

http://hdl.handle.net/11343/116072 